\title{
Santiago Trancón, Desvelos de la luz, Madrid, Huerga y Fierro, 2008, 108 pp.
}

Santiago Trancón es autor de distintos libros: un poemario, De la naturaleza del olvido (1989), una novela, En un viejo país (1997), y estudios como Teoría del teatro (2006) o Castañuela 70. Esto era España, señores (2006). Conviene que nos fijemos en dos fechas: 1989, cuando apareció el poemario citado, y 2008, cuando se publica el segundo, objeto de esta reseña, Desvelos de la luz. Casi veinte años entre uno y otro. De la naturaleza del olvido caminaba de la levedad a la concentración, de la imagen sencilla a la densidad conceptual y, fragmentado en poemas, venía a ser una única composición. Es algo que, como veremos, podemos apreciar en estos Desvelos de la $l u z$, poemario que va precedido de una poética seria, rigurosa y clarificadora. Santiago Trancón declara, frente a la opinión antigenérica, tan frecuente: "Proclamar que los géneros literarios no existen es como afirmar que la tierra es plana. Cuanto más se empeñen algunos en anunciar su desaparición, más se nos impone su existencia y necesidad". Los géneros, escribe, son "modos diversos de enunciación, con impulsos, intenciones y finalidades comunicativas". Y especifica, respecto a la poesía: “No es simple convención formal o estilística. Lo que ella ilumina, descubre y crea, no es lo mismo que convoca una novela, un cuento, una obra dramática, un ensayo o una noticia de periódico (...). La poesía selecciona, comprende y desvela aspectos de la realidad, del mundo y sus misterios, que sólo a través de ella podemos vivir y vislumbrar". Santiago Trancón procede después a caracterizar la poesía frente a otros discursos por el ritmo y la medida, la intensidad expresiva, la "verdad", el modo de enunciación subjetiva y la unión de pensamiento y emoción; en palabras del poeta: “La poesía es ritmo, respiración, cadencia. Por eso su modo natural de enunciación es el verso"; "La poesía es concisión, intensidad, concentración significativa y emocional”; “La poesía, hoy, es siempre lírica [...]. Es lírica porque no puede construirse con emociones fingidas"; "La poesía no está hecha para contar historias ni para describir cosas, sucesos o paisajes, sino para transmitir lo que el poeta siente, piensa e imagina al observar la realidad..."; "La poesía es subjetiva, pero no egocéntrica, ni narcisista": por eso, porque no es narcisista, es dialogante, comunicativa, intemporal y universal; la poesía aspira a "provocar una experiencia 
nueva en la que se une lo físico y la conciencia, el sentir y la idea [...], el yo con la objetividad del mundo". Trancón procede después a una verdadera defensa de la poesía, en la línea -pero desde una concepción moderna, claro está-, de las poéticas que se remontan a la Edad Media, a Dante, a Boccaccio o, entre nosotros, al Marqués de Santillana o a Juan del Encina. Frente a imposturas, palabrería, arbitrariedades sintácticas o de otro tipo, exhibicionismos y búsqueda de novedades a toda costa, el poeta reafirma una "poesía que provoca una experiencia única, intensa, emocional y mental a la vez, corporal y etérea, un darse cuenta del misterio que nos rodea, de la belleza y la angustia que traspasa el mundo".

Desvelos de la luz distribuye su materia poética en cinco partes de extensión parecida, con 70 poemas en total. Hay un índice externo de unidad: los poemas, sin título, van numerados dentro de cada parte. El poemario se concibe, por lo tanto, no como un agregado de poemas diversos, sino como libro, siendo evidente la unidad significativa de cada una de las partes.

En el poema inicial la luz (recuérdese el título del libro, Desvelos de la luz), se contrapone a la sombra, y la piedra (solidez, quietud) al río (a lo líquido y fluyente). Pero no son sombras totales, opacas, sino "un fulgor de sombras". Es la iluminación, por pálida que sea, lo que predomina. En ese ámbito de luces y sombras "brota un anhelo" que se une al "temblor de álamos". El anhelo implica al yo, a un yo contemplativo, perceptivo y reflexivo. Es del poeta -y a posteriori del lector- del que brotan esos anhelos, vagos tal vez, sin concreción acaso, con un punto de emoción en ese "temblor" de los álamos y quizá también del alma. A la vez que hemos interpretado superficialmente el poema, hemos podido captar algunas características por las que se define esta poesía, confirmadas con la lectura de los poemas posteriores: capacidad de sugerencia; brevedad, que supone expresión y desarrollo conciso; concentración significativa, que podemos nombrar como intensidad; tensión, aquí movida entre contrarios -luz, sombra- interdependientes, que se presuponen el uno al otro; tendencia a la instantánea más que al desarrollo temporal. A estas primeras intuiciones podemos añadir algunas otras: la presencia, explícita o no, de un yo, de un sujeto activo que observa y medita, con la luz y la sombra como 
elementos fundamentales de su visión; un mismo clima emocional, una misma tonalidad sentimental que en estos primeros poemas es adscribible a los términos luz y sombras; tradicionalmente, la luz connota elementos positivos reales (claridad, visión, calor, etc.) o simbólicos (desvelar, pureza de las cosas, renacer, etc.), y la sombra, la oscuridad o la noche, elementos negativos, reales también (dificultades de percepción y movimiento...) y simbólicos (opacidad de un texto, incertidumbre vital, duda, lo insondable, etc.). Cuando el poeta dice “Quisiera ver la luz del amanecer. / Luz de pájaros y racimos y espigas / que un niño lleva bajo el brazo / para alumbrar la sombra de los pozos", toda una serie de imágenes venturosas vienen a la mente: la pureza con que la luz del amanecer va delineando, delimitando las cosas, el mundo; es como un renacer, como si la vida apareciera cada día con la primera luz del mundo. En cambio, si leemos: “Llegó la noche como un alacrán”, otra serie opuesta de imágenes nos atenaza y sobrecoge: el miedo, el peligro, la herida, la muerte... Estas connotaciones las expresa el poeta por medio de una figura retórica formada por términos que se excluyen desde el punto de vista del significado: el oxímoron, que se ofrece como fórmula de fusión de contrarios; en los poemas de Trancón encontramos: oscura luz, fuego negro, llama oscura, luz negra...; es curioso observar cómo los calificativos "oscuro" y "negro" cobran un relieve significativo muy fuerte, al teñir de tinieblas la claridad del fuego, de la llama o de la luz: predomina el túnel sobre la salida, pudiéramos decir.

Aspecto importante del poemario es el recurso a los símbolos: hay complejos mentales, sentimentales o de otro tipo difíciles de explicar y el símbolo puede configurar en una palabra todo aquel complejo interior: perdido entre sombras, incertidumbres y miedos, el poeta escribe: “Pero sé que más allá hay un sendero / que puedo recorrer, y fuentes a lo largo / del camino que apagan momentáneamente la sed". Tanto el sendero como las fuentes como la sed remiten a un estatuto simbólico: “Un galope de caballos antiguos / atraviesa la noche” ¿Qué caballos son esos fuera del ámbito simbólico? Y la misma pegunta nos hacemos ante otros caballos que aparecen en distintos poemas: “Caballos negros, cubiertos de zarzas, se precipitan al mar": sentimientos de desolación, desconcierto y muerte acudirán en una inicial interpretación; los "caballos guerreros" del poema séptimo de la tercera 
parte, responden a lo que Carlos Bousoño llamó “visión", pero es además, en el sentido corriente, una visión apocalíptica, aterradora, como si esos simbólicos caballos, espoleados por "serpientes de humo", se precipitaran hacia el abismo. Junto a los símbolos destacan las imágenes, que normalmente materializan una visión o un pensamiento. Podemos degustar algunas: "El crepúsculo es un surco oxidado que llega hasta el infinito"; "Un anhelo de raíces asciende hacia la copa de los chopos"; "La noche es ya un navío errante cargado de sombras"; el fruto morado de la higuera es "vulva solar que picotean los gorriones"; el grillo es "ruiseñor de azabache", las amapolas, "frágiles copas que recogen el rubor del viento", etc., etc.

Me referiré finalmente al contenido en cada una de las partes del poemario. Si la primera, "Fulgor de sombras", expresa los contrarios en su mismo enunciado, enfrentados como dos polos, positivo y negativo, sólo fusionados formalmente a través del oxímoron, la segunda parte, "Donde la quietud", poetiza un ámbito natural sereno donde el sujeto puede mirar, admirar y meditar, con impresiones íntimas de una pareja quietud que trasciende hacia la visión de un tiempo detenido, una eternidad que es "la eternidad de un instante" y, por ello, fugaz, "fugaz eternidad", nuevo oxímoron hacia el sentido de la inmovilidad, la lentitud de todo, como si la muerte detuviera también su paso, como si todo -también el almareposara, quieta, ajena al decurso temporal, como si el mundo natural permaneciera inmóvil y en él pudiera brotar el anhelo, ese signo recurrente en esta poesía: "el anhelo de reposo" dice un poema, de reposo no perturbado por accidentes como la noche o las sombras, por "la inquietud que penetra en los rumores de lo oscuro", como expresa otra composición. El logro de ese anhelo supondría tal vez una plenitud que el poeta ve, de momento, fuera de sí, en el mundo natural, "serena plenitud sin mí”, pero que persiste como vehemente afán: “Y mis cansados ojos (...) / siguen buscando / la huella incandescente, el fulgor de la quietud en el centro de la noche".

En la tercera parte, "Teoría de la incertidumbre", los signos negativos se acumulan: sol lánguido, pupilas sin rumbo, ramas quebradas..., son imágenes o sintagmas en los que el sustantivo se hace acompañar por un calificativo que matiza 
negativamente su significado: atardeceres disecados, racimos oxidados, vacas moribundas, cielo de plomo... Estos signos brotan de un estado de ánimo desolado, perplejo y angustiado ante la vida y, si hacemos caso al poema octavo, ante el decurso temporal, volviéndose el sujeto hacia esa etapa en que lo temporal no es perceptible: "Infancia feliz, sin miedo a los relojes", "los instantes en que fui feliz". Predomina, en cambio, el ahora desolado, el vacío interior, "la incertidumbre de la espera", el vacío interior del que parece salir el sujeto en los versos finales, que alumbran, creo, un tiempo nuevo: "Pero regresé de día y despierto. / ¡Oh la dicha del regreso!".

"El cielo encendido" es el título de la cuarta parte: el tenebroso paisaje interior de la parte tercera es ahora luminoso, alegre, leve, aéreo. Retornan las sensaciones que entran por los ojos: nubes que refulgen, agua que brota y ríe, etc. Cada poema, breve y leve, es como una instantánea de luz, un cuadro, un lienzo en el que los objetos componen un paisaje risueño, reflejo de otro paisaje interior que se trasvasa a los ojos que miran. No es extraño que reaparezca el amanecer como momento auroral del renacer del corazón, merced, sin duda, a un tú que enciende el cielo del título y los ojos del yo contemplativo y admirativo. De ambas actitudes derivan imágenes de una gran delicadeza: “Tu voz llegaba a mi corazón / como un rumor de pétalos cayendo al agua”; “Una luz de oro acariciaba la seda de tus pechos”. Pero frente al amanecer, el crepúsculo llega con sus signos acuciantes: “Llega sigilosa la noche. / La lluvia, lenta, como nieve, / empieza a caer sobre mis ojos"; el temor sobreviene, la incertidumbre otra vez: "Ya nada es seguro en mi corazón”. ¿Todo momentáneo? Así parece: el desasosiego que ha sobrevenido, el ahogo interior parecen resolverse, pues se reproducen las imágenes delicadas y luminosas: "zarcillos de verde luz casi transparente", "la llanura encendida de amapolas"... ¿Aceptación del destino temporal? Así lo pensamos a la luz del poema final de esta parte.

La parte final del poemario lleva por título "Plenitud del vacío". Con este título parece que nos asomamos a abismos místicos, al vacío que podemos hallar expresado por un San Juan de la Cruz, por ejemplo, pero con una diferencia: el santo de Ávila canta desde la fe, se expresa desde una concepción religiosa; en la poesía de 
Trancón no aparece para nada ni la impregnación religiosa ni la fe. Plenitud del vacío. Difícil nos resulta concebir un vacío lleno, pleno. También lo es para el poeta, dado que el oxímoron traduce una experiencia inefable. De ahí que el poeta recurra a imágenes, ante la dificultad inicial de expresarlo de otra manera: "La plenitud es vacía como la gota de rocío / que tiembla y cae de la hoja que yo acaricié”; “El eco, el vacío que deja la ola al morir"... ¿El vacío fértil de los místicos? ¿el vaciamiento del alma? Son preguntas que nos hacemos a medida que van discurriendo los poemas. Silencio, muerte, vacío, plenitud. La muerte-vacío como plenitud, la nada como destino, la plenitud vacía. El "no pensar", el "no lugar", el estar "no siendo", "una llama que colma y no quema": son expresiones que nos hablan de ese después, del anhelo de reposo, de la quietud definitiva a la que las formas parecen tender. "Ese ya no ser" -abandono, quietud, vacío, transparencia- prefigura la muerte, el ser no siendo que la poesía vislumbra, intuye y hasta intenta revelar. Acaso sea el poema penúltimo del libro el que reúna gran parte de las preocupaciones de esta parte final: la buscada actitud de serenidad para reflexionar sobre lo que no se acepta; el deseo de eternizar el instante o de imaginar la eternidad del instante; la poesía como posible terapia sanadora, según la vieja concepción aristotélica, el inevitable pavor ante la muerte y la esperanza final como deseable posibilidad.

José Enrique Martínez 